\title{
POTENSI DAN STRATEGI MARKETING PERBANKAN SYARIAH PADA SEGMEN KELAS MENENGAH INDONESIA
}

\author{
Sofyan Rizal ${ }^{*}$
}

\begin{abstract}
Potential and Marketing Strategy of Islamic Banking in Indonesia's Middle Class Segment. Group of middle-class society is a tremendous market for Islamic business, especially Islamic banking. The fact that the majority of Indonesia's population is Muslim, Islamic business institutions should work on the mid-market segment earnestly. The potential of middle class development in Indonesia gives an opportunity for Islamic banks to compete in the market. Various characteristics of the middle class used as a valuable input in conducting market segmentation, targets, and formulate strategies to create the accepted products.
\end{abstract}

Keywords: strategy, marketing, islamic banking, midle-class

\begin{abstract}
Abstrak: Potensi dan Strategi Marketing Perbankan Syariah pada Segmen Kelas Menengah Indonesia. Kelompok masyarakat kelas menengah adalah pasar yang luar biasa bagi bisnis syariah, khususnya perbankan syariah. Fakta bahwa penduduk Indonesia mayoritas beragama Islam, sejatinya lembaga bisnis syariah menggarap segmen pasar kelas menengah ini dengan sungguh-sungguh. Kelas menengah yang terus berkembang dan sangat berpotensi di Indonesia adalah sebuah peluang bagi perbankan syariah untuk berkompetisi dan turut memperebutkan pasar tersebut. Pelbagai macam karakteristik dari kelas menengah menjadi masukan berharga sebagai dasar dalam melakukan segmentasi pasar, target, dan merumuskan strategi dalam menciptakan produk yang bisa diterima.
\end{abstract}

Kata Kunci: strategi, marketing, perbankan syariah, kelas menengah

Naskah diterima: 4 Januari 2013, direvisi: 23 Maret 2013, disetujui: 28 Maret 2013.

* Universitas Nasional (Unas) Jakarta. Jalan Sawo Manila, Pejaten, Pasar Minggu, Jakarta. Email: sofyanrizal@yahoo.com 


\section{Pendahuluan}

Saat ini, Indonesia menjadi salah satu negara dengan pertumbuhan ekonomi yang cepat di Asia, bahkan di dunia. Pertumbuhan ekonomi Indonesia mencapai $6 \%{ }^{1}$, dan masih terus berpotensi untuk tumbuh karena didorong oleh fundamental ekonomi yang baik. Income per kapita Indonesiapun terus tumbuh. Saat ini saja, income sudah menembuh angka $\$ 3500^{2}$, dan diperkirakan oleh BI tahun 2014, pendapatan per kapita Indonesia sudah menembus angka $\$ 4000^{3}$. Fenomena pertumbuhan ekonomi yang baik ini memicu tumbuhnya kelas menengah di Indonesia. Berdasarkan data dari Bank Pembangunan Asia (ADB), pada 2010, penduduk kelas menengah Indonesia telah mencapai 135 Juta orang atau $56 \%$ dari total jumlah penduduk ${ }^{4}$. Jumlah sebesar itu tentu saja sebuah potensi yang besar dilihat dari pasar pelbagai macam produk. Tidak berlebihan, karena potensi konsumsi pasar kelas menengah tersebut mencapai Rp 7695 trilyun $^{5}$.

Melihat potensi di atas, sesungguhnya kelas menengah adalah sebuah pasar yang luar biasa bagi semua bidang usaha, tidak terkecuali lembaga bisnis syariah, khususnya perbankan syariah. Dengan asumsi bahwa mayoritas penduduk Indonesia beragama Islam, begitupun dengan kelas menengah Indonesia, maka lembaga bisnis syariah sudah seharusnya menggarap dengan serius segmen pasar kelas menengah yang sangat potensial ini.

Salah satu lembaga bisnis syariah yang paling berpeluang dalam menggarap pasar ini adalah perbankan syariah. Hal ini karena berdasarkan karakteristik penggolongannya, kelas menengah memiliki potensi berinvestasi yang lebih besar, karena dari segi pendapatan per kapita, kebutuhan untuk konsumsi dasar pada kelas menengah sudah terlewati, sehingga mereka punya potensi untuk dimodalisasi sebagai sumber dana pihak ketiga atau konsumen (nasabah) produk-produk perbankan. Namun, untuk masuk serius menggarap segmentasi kelas menengah Indonesia, perbankan syariah perlu memiliki pe-

1 Tepatnya 6,02\%. Baca, Laporan Badan Pusat Statistik tentang pertumbuhan ekonomi Indonesia 2013, dalam www.bps.go.id

2 Tepatnya \$ 3420. Lihat, laporan Worldbank, http://data.worldbank.org/country/id\#cp_wdi. Perkiraan BPS pun tidak jauh berbeda, dalam rupiah, pendapatan Indonesia mencapai hampir tiga Jutaan pada 2012, dalam www.bps.go.id

${ }^{3}$ www.antaranews.com/berita/347545/bi-2014-pendapatan-perkapita-4000-dolar-as.

${ }^{4}$ Laporan Asian Development Bank pada Key Indicator For Asia and Pasific 2010, SPECIAL CHAPTER The Rise of Asia's Middle Class, 41 ${ }^{\text {st }}$ Edition, , Asian DevelopmentBank, August 2010.

${ }^{5}$ Laporan utama dari majalah SWA bertajuk "Dasyatnya Daya Beli Kelas Menengah", menyebutkan bahwa potensi konsumsi kelas menengah Indonesia mencapai 769,5 trilyun rupiah. SWA 02/XXII/23 Januari-6 Februari 2013, h. 26. 
ngetahuan yang cukup, agar strategi marketing yang diterapkan dapat menjadi tepat.

Berdasarkan paparan di atas, maka tulisan ini ingin menjawab pertanyaan tentang bagaimana potensi kelas menengah Indonesia, khususnya pada perbankan syariah, dan bagaimana strategi marketing perbankan syariah yang tepat untuk menggarap segmen kelas menengah Indonesia.

\section{Siapa Kelas Menengah Indonesia?}

Kelas menengah adalah fenomena yang menarik yang biasanya timbul karena terus tumbuhnya ekonomi suatu negara. Semakin tinggi pertumbuhan ekonomi suatu negara, maka semakin tumbuh pula kelas menengah di negara tersebut. Dalam perspektif pemasaran, kelas menengah tentu dilihat dari potensi untuk membeli produk atau purchasing power dari segmen tersebut. Berdasarkan hal itu, maka dapat diambil definisi dari kelas menengah yang melihat dari perspektif pendapatan per kapita seseorang yang dapat digolongkan menjadi kelas menengah.

Menurut ADB, kelas menengah adalah penduduk yang memiliki pengeluaran per kapita per hari di kisaran $\$ 2-\$ 20^{6}$. Berdasarkan pedoman itu, dengan kurs Rp 10.000 ini berarti golongan kelas menengah adalah orang dengan pendapatan setara dengan Rp 20.000-200.000/hari atau Rp 600.000-6.000.000/bulan.

Dengan dasar perhitungan seperti itu, maka wajar jika jumlah kelas menengah Indonesia sangat besar, sekira 135 juta orang atau sekira 56\% dari jumlah penduduk Indonesia. Jika potensi itu dikonversi menjadi peluang bisnis, maka terdapat pasar sekira $700 \mathrm{~T}$ dari kelas menengah. Jumlah yang luar biasa jika digarap secara serius dan fokus.

Namun tentu saja yang penting adalah bukan sekadar jumlah penduduk menengah yang besar, melainkan bagaimana pendapatan kemudian mewujud menjadi daya beli yang memadai. Dalam perhitungan demografi, kelas menengah ini kemudian terbagi menjadi tiga kelompok, yaitu: kelompok kelas menengah bawah dengan batasan $\$ 2$-\$4 per kapita, kelompok kelas menengah pertengahan dengan batasan \$4-10, dan kelas menengah atas dengan batasan $\$$ 10-20 per kapita per hari ${ }^{7}$.

Angka-angka di atas tentu tidak akan berarti banyak jika hanya sekadar data statistik saja. Potensi pasar kelas menengah dengan data statistik tersebut

${ }^{6}$ Lihat dalam laporan Asian Development Bank pada Key Indicator for Asia and Pasific 2010, SPECIAL CHAPTER The Rise of Asia's Middle Class, $41^{\text {st }}$ Edition, , Asian Development Bank, August 2010, h. 5.

${ }^{7}$ Laporan Asian Development Bank pada Key Indicator For Asia and Pasific 2010, h. 9. 
akan lebih berarti jika diikuti dengan pelbagai macam informasi tambahan mengenai pelbagai macam hal yang berkaitan dengan strategi segmentasi.

Temuan survai dari Center for Middle Class Studies bekerjasama dengan majalah $\mathrm{SWA}^{8}$, dapat menjadi acuan kita untuk melihat dan melengkapi secara lebih mendalam potret dari kelas menengah baik secara demografis maupun secara psikografis. Pelbagai macam temuan tersebut dapat kita sinergikan dengan bagaimana strategi segmentasi yang bisa dilakukan oleh perbankan syariah dalam menggarap pasar kelas menengah.

\section{Segmentasi dan Profil Psikografis}

Segmentasi pasar adalah kegiatan membagi pasar yang bersifat heterogen dari suatu produk ke dalam satuan pasar yang bersifat homogen atau suatu proses membagi pasar kedalam segmen yang potensial dengan kesamaan karakteristik yang menunjukkan adanya kesamaan perilaku konsumen ${ }^{9}$.

Segmentasi dilakukan karena perusahaan tidak dapat berfokus pada semua pasar atau tidak dapat memuaskan pelbagai macam segmen yang ada di masyarakat. Perusahaan memiliki sumber daya yang terbatas, sehingga agar efisien dan efektif, maka pasar harus dipilih, di pilah, dan kemudian masuk kedalam pasar yang paling potensial. Jika perusahaan tidak melakukan segmentasi ini, kemudian terjebak melakukan generalisasi dan menggarap semua pasar, maka tanpa sumber daya yang memadai, perusahaan akan kewalahan dan hasilnya akan mengecewakan konsumennya.

Segmentasi pasar dilakukan dengan pelbagai macam pendekatan, dari pendekatan tradisional, misalnya pendekatan geografis dan pendekatan demografis, sampai pada pendekatan psikografis. Pendekatan geografis adalah pendekatan berdasarkan daerah atau wilayah, sedangkan pendekatan demografis adalah pendekatan berdasarkan umur, tingkat pendidikan, dan tingkat pendapatan. Pendekatan yang lebih dalam lagi adalah psikografis. Pendekatan ini melihat segmentasi berdasarkan value dan perilaku konsumen, yang merupakan faktor yang sangat penting dalam keputusan untuk memakai $\operatorname{produk}^{10}$.

Langkah selanjutnya dari strategi segmentasi adalah targeting. Targeting adalah proses evaluasi dan pemilihan dari sgmentasi. (marketing the basic $h$.

${ }^{8}$ Majalah SWA edisi 02/XXIX/23 Januari-6Februari 2013 bekerjasama dengan CMCS (Center for Middle Class Studies) mempublikasikan hasil survai yang sangat menarik tentang kelas menengah Indonesia. Hasil survai inilah yang menjadi salah satu acuan data dalam menyusun tulisan ini.

${ }^{9}$ Moore and Pareek, Marketing the Basics, (New York: Routledge, 2006), h. 132.

${ }^{10}$ Lebih lengkap tentang segmentasi psikografis ini lihat dalam Kotler, Marketing Management Millenium Edition, (New Jersey: Prentice-Hall Inc, 2000), h. 148-150. 
142). Perusahaan harus memutuskan segmen yang mana yang akan dituju. Setelah target ditetapkan, maka perusahaan harus mengalokasikan segala sumber daya pada target yang telah dipilihnya. Ketika target sudah ditetapkan maka perusahaan dapat fokus dengan mengalokasikan lebih banyak sumber daya kepada pelanggan yang lebih valuable. Valuable konsumen berhak mendapatkan jasa yang lebih premium, sementara yang bukan, akan mendapatkan sumber daya yang biasa ${ }^{11}$.

Jika kita kaitkan dengan kelas menengah Indonesia, maka pembagian kelas menengah berdasarkan dari pendapatannya semata, adalah segmentasi berdasarkan pendekatan demografis. Kelas mengah dengan pendapatan $\mathrm{Rp}$ 600.000-1.200.000/bulan, kelas menengah dengan pendapatan $\mathrm{Rp}$ 1.200.0003.000.000/bulan dan kelas menbgtah dengan pendapatan $\mathrm{Rp}$ 3.000.000$6.000 .000 /$ bulan.

Segmentasi berdasarkan demografis ini tentu belum dapat menjelaskan secara lebih lengkap, tentang preferensi konsumen, dan masih bersifat terlalu umum. Untuk menerjemahkannya ke dalam suatu strategi pemasaran dan menginterpretasikannya menjadi strategi, segmentasi berdasarkan demografis ini masih terlalu dangkal.

Oleh karena itulah, sebagai masukan dalam penyusunan strategi pemasaran, digunakan segmentasi kelas menengah berdasarkan psikografis, karena salah satu proses melakukan segmentasi yang baik adalah dengan melakukan profiling pada pasar yang akan disegmentasi ${ }^{12}$. Proses profiling inilah yang membutuhkan informasi yang lengkap tentang pelbagai macam, termasuk perilaku dan karakteristik konsumen. Pendekatan segmentasi psikografis adalah salah satu cara yang baik dalam melihat segmen lebih lengkap dan mendalam.

\section{Segmentasi Psikografis Kelas Menengah Indonesia}

Riset dari Banerjee dan Duflo, dapat memberikan kita masukan yang berharga tentang karakteristik perilaku kelas menengah. Dalam hal membelanjakan uangnya, kelas menengah cenderung menginginkan membelanjakan uangnya untuk makanan, hiburan, dan hidup yang lebih berkualitas ${ }^{13}$. Ini artinya, perilaku kelas menengah dalam mengonsumsi lebih mengutamakan kualitas

${ }^{11}$ Lihat dalam Kotler, Marketing Management Millenium Edition, (New Jersey: Prentice-Hall Inc, 2000), h. 154-156; Lihat pula dalam Mussry, dkk, The Next Marketing Strategy, That's Work, (Jakarta: Gramedia, 2007), h. 22.

12 Baca lebih lengkap bagaimana proses melakukan profiling dalam Kotler, Marketing Management Millenium Edition, h. 147.

${ }^{13}$ Banerjee \& Duflo, "What is Middle Class about the Middle Classes around the World?", dalam Journal of Economic Perspectives, 2008, h. 3. 
produk yang lebih baik. Dalam hal keterkaitan dengan perbankan dan investasi, kelas menengah cenderung sudah menaruh perhatian pada pelbagai macam instrumen, misalnya berinvestasi dalam kegiatan perekonomian riil, melalui perbankan, atau investasi pada aset produktif ${ }^{14}$. Kelas menengah selain merupakan pasar bagi industri jasa perbankan dan merupakan pasar yang menarik untuk jasa keuangan lain seperti asuransi dan dana investasi masa depan, karena karakteristik kelas menengah adalah cenderung peduli dan berinvestasi pada pendidikan anak dan kesehatan. Informasi ini memberitahukan kita pada perilaku kelas menengah yang potensial dapat dijadikan masukan untuk membuat strategi yang tepat bagi marketing.

Survei yang lebih dalam lagi bisa kita dapati dalam riset CMCS mengenai potensi pasar kelas menengah Indonesia. Riset ini secara terperinci mengungkap bagaimana perilaku kelas menengah Indonesia yang dapat dijadikan acuan untuk strategi marketing.

Berbasis pada segmen yang dipakai untuk membagi kelas menengah dari ADB, CMCS mengembangkan segmen kelas menengah menjadi lebih detil dengan delapan kelas berdasarkan daya beli, yang masing-masing mewakili karakteristik yang berbeda yang dinilai dari tiga aspek, yaitu: kepemilikan sumber daya (ownership of resourchs), tingkat pengetahuan (knowledgeability), dan tingkat koneksi social (social connection). Hasil dari studi tersebut antara lain: aspirator, performer, expert, climber, trendsetter, follower, settler, dan follower ${ }^{15}$.

Empat kelompok pertama (climber, performer, flow-er, follower), memiliki sumber daya yang lebih rendah (juga memiliki daya beli yang rendah). Sedangkan Kelompok kedua (expert, aspirator, settler, dan trend setter) memiliki sumber daya yang lebih baik dan berdaya beli lebih tinggi. Dari segi karakteristik, survai tersebut juga mengungkap beberapa hal yang sangat berguna bagi penyusunan strategi pemasaran.

Berdasarkan survai, secara segmentasi psikografis, didapat pelbagai karakteristik yang detil tentang masing-masing segmen kelas menengah Indonesia tersebut, antara lain:

${ }^{14}$ Asian Development Bank pada Key Indicator For Asia and Pasific 2010, h. 3-4.

${ }^{15}$ Lebih lengkap baca, "Karakteristik 8 Segmen Kelas Menengah Indonesia", Majalah SWA/02 /XXIX/ 23 Januari-6 Februari 2013, h. 32. 


\begin{tabular}{|c|c|c|c|c|c|c|c|c|}
\hline $\begin{array}{l}\text { Karak- } \\
\text { teristik }\end{array}$ & $\begin{array}{l}\text { Aspi- } \\
\text { rator }\end{array}$ & $\begin{array}{c}\text { Perfor- } \\
\text { mer }\end{array}$ & Expert & $\begin{array}{l}\text { Clim- } \\
\text { ber }\end{array}$ & $\begin{array}{l}\text { Trend- } \\
\text { setter }\end{array}$ & $\begin{array}{l}\text { Follo- } \\
\text { wer }\end{array}$ & Settler & Flow-er \\
\hline $\begin{array}{l}\text { Tujuan } \\
\text { Hidup }\end{array}$ & $\begin{array}{l}\text { Kontri- } \\
\text { busi } \\
\text { pada } \\
\text { sesama }\end{array}$ & $\begin{array}{l}\text { Penca- } \\
\text { paian } \\
\text { dalam } \\
\text { karier }\end{array}$ & $\begin{array}{l}\text { Punya } \\
\text { ekspertis } \\
\text { di antara } \\
\text { rekan } \\
\text { dan } \\
\text { kolega }\end{array}$ & $\begin{array}{l}\text { Meraih } \\
\text { kebebas- } \\
\text { an finan- } \\
\text { sial }\end{array}$ & $\begin{array}{l}\text { Menjadi } \\
\text { contoh } \\
\text { dan } \\
\text { teladan } \\
\text { bagi } \\
\text { orang } \\
\text { lain }\end{array}$ & $\begin{array}{l}\text { Eksis di } \\
\text { komu- } \\
\text { nitas }\end{array}$ & $\begin{array}{l}\text { Ketena- } \\
\text { ngan } \\
\text { hidup }\end{array}$ & $\begin{array}{l}\text { Kehidu- } \\
\text { pan yang } \\
\text { lebih baik }\end{array}$ \\
\hline $\begin{array}{l}\text { Faktor } \\
\text { Penting } \\
\text { dalam } \\
\text { hidup }\end{array}$ & $\begin{array}{l}\text { Terwu- } \\
\text { jud ma- } \\
\text { syarakat } \\
\text { yang } \\
\text { lebih } \\
\text { baik }\end{array}$ & $\begin{array}{l}\text { Sukse } \\
\text { karier } \\
\text { dan } \\
\text { bisnis }\end{array}$ & $\begin{array}{l}\text { Penca- } \\
\text { paian } \\
\text { standar } \\
\text { ekspertis } \\
\text { yang } \\
\text { tinggi }\end{array}$ & $\begin{array}{l}\text { Peker- } \\
\text { jaan } \\
\text { yang } \\
\text { lebih } \\
\text { baik } \\
\text { demi } \\
\text { keluarga } \\
\end{array}$ & $\begin{array}{l}\text { Punya } \\
\text { penga- } \\
\text { ruh terha- } \\
\text { dap } \\
\text { orang } \\
\text { lain }\end{array}$ & $\begin{array}{l}\text { Ikut } \\
\text { trend }\end{array}$ & $\begin{array}{l}\text { Agama } \\
\text { dan } \\
\text { spiritual }\end{array}$ & $\begin{array}{l}\text { Sukses } \\
\text { anak } \\
\text { sebagai } \\
\text { generasi } \\
\text { penerus }\end{array}$ \\
\hline $\begin{array}{l}\text { Persepsi } \\
\text { tentang } \\
\text { hidup }\end{array}$ & $\begin{array}{l}\text { Berkon- } \\
\text { tribusi } \\
\text { dan } \\
\text { menjadi } \\
\text { inspirasi } \\
\text { orang } \\
\text { lain } \\
\end{array}$ & $\begin{array}{l}\text { Hidup } \\
\text { adalah } \\
\text { persai- } \\
\text { ngan }\end{array}$ & $\begin{array}{l}\text { Hidup } \\
\text { adalah } \\
\text { belajar }\end{array}$ & $\begin{array}{l}\text { Hidup } \\
\text { adalah } \\
\text { mengejar } \\
\text { impian }\end{array}$ & $\begin{array}{l}\text { Menjadi } \\
\text { terdepan }\end{array}$ & $\begin{array}{l}\text { Hidup } \\
\text { adalah } \\
\text { tentang } \\
\text { konfor- } \\
\text { mitas }\end{array}$ & $\begin{array}{l}\text { Stabili- } \\
\text { tas dan } \\
\text { kenya- } \\
\text { manan }\end{array}$ & $\begin{array}{l}\text { Hidup } \\
\text { adalah } \\
\text { perjua- } \\
\text { ngan }\end{array}$ \\
\hline $\begin{array}{l}\text { Norma } \\
\text { dan nilai }\end{array}$ & $\begin{array}{l}\text { Nilai } \\
\text { universal }\end{array}$ & $\begin{array}{l}\text { Nilai } \\
\text { global, } \\
\text { Prestasi, } \\
\text { Kompe- } \\
\text { tisi, } \\
\text { Aktuali- } \\
\text { sasi, } \\
\text { berasi } \\
\text { meng- } \\
\text { ambil } \\
\text { resiko } \\
\end{array}$ & $\begin{array}{l}\text { Belajar } \\
\text { sepan- } \\
\text { jang } \\
\text { hidup }\end{array}$ & $\begin{array}{l}\text { Kerja } \\
\text { keras, } \\
\text { produk- } \\
\text { tif, orien- } \\
\text { tasi } \\
\text { keluarga }\end{array}$ & $\begin{array}{l}\text { Bagian } \\
\text { dari } \\
\text { trend, } \\
\text { menjadi } \\
\text { yang } \\
\text { terdepan }\end{array}$ & $\begin{array}{l}\text { Diakui } \\
\text { eksis- } \\
\text { tensinya, } \\
\text { keber- } \\
\text { samaan, } \\
\text { setia } \\
\text { kawan }\end{array}$ & $\begin{array}{l}\text { Harmoni } \\
\text { dalam } \\
\text { idup, } \\
\text { konser- } \\
\text { vatif, } \\
\text { nyaman, } \\
\text { respek } \\
\text { terhadap } \\
\text { nilai } \\
\text { tradisi }\end{array}$ & $\begin{array}{l}\text { Keama- } \\
\text { nan, nilai } \\
\text { keluarga, } \\
\text { mejaga } \\
\text { tradisi }\end{array}$ \\
\hline Motivasi & $\begin{array}{l}\text { Berkon- } \\
\text { tribusi } \\
\text { pada } \\
\text { masya- } \\
\text { rakat }\end{array}$ & $\begin{array}{l}\text { Pertum- } \\
\text { buhan } \\
\text { personal }\end{array}$ & $\begin{array}{l}\text { Terde- } \\
\text { pan } \\
\text { dalam } \\
\text { keahlian }\end{array}$ & $\begin{array}{l}\text { Kelas } \\
\text { sosial } \\
\text { ekonomi } \\
\text { yang } \\
\text { lebih baik }\end{array}$ & $\begin{array}{l}\text { Terde- } \\
\text { pan } \\
\text { dalam } \\
\text { tren }\end{array}$ & $\begin{array}{l}\text { Diterima } \\
\text { oleh } \\
\text { komu- } \\
\text { nitas }\end{array}$ & $\begin{array}{l}\text { Seim- } \\
\text { bang } \\
\text { materi } \\
\text { dan } \\
\text { spiritual }\end{array}$ & $\begin{array}{l}\text { Stabilitas } \\
\text { dan } \\
\text { keama- } \\
\text { nan } \\
\text { dalam } \\
\text { hidup }\end{array}$ \\
\hline $\begin{array}{l}\text { Relasi } \\
\text { Sosial }\end{array}$ & $\begin{array}{l}\text { Terhu- } \\
\text { bung } \\
\text { dengan } \\
\text { isu } \\
\text { universal, } \\
\text { aktiv } \\
\text { dalam isu } \\
\text { publik }\end{array}$ & $\begin{array}{l}\text { Gabung } \\
\text { dalam } \\
\text { komu- } \\
\text { nitas } \\
\text { dalam } \\
\text { rangka } \\
\text { aktua- } \\
\text { lisasi }\end{array}$ & $\begin{array}{l}\text { Menjalin } \\
\text { jaringan } \\
\text { profe- } \\
\text { sional } \\
\text { untuk } \\
\text { menun- } \\
\text { jang } \\
\text { keahlian }\end{array}$ & $\begin{array}{l}\text { Kehar- } \\
\text { monisan } \\
\text { dalam } \\
\text { kelaurga }\end{array}$ & $\begin{array}{l}\text { Berusa- } \\
\text { ha men- } \\
\text { jadi } \\
\text { pusat } \\
\text { perha- } \\
\text { tian }\end{array}$ & $\begin{array}{l}\text { Menjaga } \\
\text { agar } \\
\text { tetap } \\
\text { relevan } \\
\text { di tengah } \\
\text { masya- } \\
\text { rakat }\end{array}$ & $\begin{array}{l}\text { Berga- } \\
\text { bung } \\
\text { dalam } \\
\text { kegiatan } \\
\text { masya- } \\
\text { rakat, } \\
\text { agama }\end{array}$ & $\begin{array}{l}\text { Menjaga } \\
\text { keber- } \\
\text { samaan } \\
\text { keluarga }\end{array}$ \\
\hline
\end{tabular}




\begin{tabular}{|c|c|c|c|c|c|c|c|c|}
\hline $\begin{array}{l}\text { Pola } \\
\text { mana- } \\
\text { jemen } \\
\text { Aset }\end{array}$ & $\begin{array}{l}\text { Investasi } \\
\text { jangka } \\
\text { panjang } \\
\text { bersivat } \\
\text { konser- } \\
\text { vatif }\end{array}$ & $\begin{array}{l}\text { Investasi } \\
\text { jangka } \\
\text { pendek } \\
\text { yang } \\
\text { cepat } \\
\text { meng- } \\
\text { hasilkan }\end{array}$ & $\begin{array}{l}\text { Berhati- } \\
\text { hati da- } \\
\text { lam pola } \\
\text { investasi } \\
\text { standar } \\
\text { (deposi- } \\
\text { to, tanah, } \\
\text { properti, } \\
\text { dll) }\end{array}$ & $\begin{array}{l}\text { Investasi } \\
\text { terbatas } \\
\text { (tabu- } \\
\text { ngan, } \\
\text { emas) }\end{array}$ & $\begin{array}{l}\text { Investasi } \\
\text { pada } \\
\text { instru- } \\
\text { men } \\
\text { resiko } \\
\text { tinggi }\end{array}$ & $\begin{array}{l}\text { Investasi } \\
\text { terbatas } \\
\text { (tabung- } \\
\text { an, rek- } \\
\text { sadana) }\end{array}$ & $\begin{array}{l}\text { Investasi } \\
\text { tradisi- } \\
\text { onal } \\
\text { (tanah, } \\
\text { properti, } \\
\text { emas) }\end{array}$ & $\begin{array}{l}\text { Investasi } \\
\text { terbatas } \\
\text { (tabu- } \\
\text { ngan, } \\
\text { emas) }\end{array}$ \\
\hline
\end{tabular}

Karakteristik middle class Indonesia berdasarkan segmentasi psikografis Sumber: Survei Kelas Menengah Indonesia 2013, CMCS. Data dioleh

\section{Peluang Segmen Kelas Menangah bagi Perbankan Syariah}

Berdasarkan karakteristik di atas, dapat dipetakan potensi dari setiap segmen psikografis yang diperlukan terutama untuk industri perbankan syariah. Pertama, segmen aspirator, memiliki perilaku filantropis yang tinggi, mempunyai kepedulian pada orang lain, memiliki motivasi untuk berkontribusi pada masyarakat, peduli dengan nilai moral, berwawasan luas melalui relasi sosial yang tinggi, memilih berinvestasi jangka panjang yang bersifat konservatif, misalnya: deposito, pasar saham, surat utang negara, reksadana, emas, atau properti. Karakter tersebut, jika dihubungkan dengan potensi perbankan syariah, mereka adalah pasar yang potensial terutama ketika kita mengedepankan fiturfitur perbankan syariah yang sifatnya spiritual dan emosional, misalnya menonjolkan religuitas atau produk yang menunjukkan kepedulian kepada sesama.

Kedua, segmen expert, memiliki perilaku ingin terus berkembang dan belajar, mencoba hal yang baru, dan memiliki pola manajemen asset yang konservatif, selalu berhati-hati dalam berinvestasi, sehingga memilih investasi yang standar. Melihat karakter di atas, fitur yang dapat diunggulkan dari perbankan syariah untuk segmen ini adalah produk yang senantiasa baru atau produk standar dengan keamanan yang tinggi, seperti deposito.

Ketiga, trendsetter, memiliki sifat ingin selalu update dan berusaha menjadi yang pertama dalam trend di masyarakat, namun memilih investasi pada instrumen investasi berisiko tinggi. Segmen ini mungkin kurang tepat dikembangkan oleh perbankan syariah, mengingat pola investasi mereka.

Keempat, settler, memiliki karakterisitik mengedepankan keamanan dan keseimbangan dalam hidup, sehingga memilih investasi yang tradisional dan aman, tidak beresiko tinggi. Segmen ini cocok untuk fitur produk perbankan syariah yang mengedepankan sisi religius (seperti: aman, sesuai dengan syariah, halal, berkah) dan investasi jangka panjang yang aman seperti investasi pada dana pensiun. 
Kelima, karakteristik performer antara lain sukses dalam karier, ingin bersaing, dan kompetitif, terbuka, dan memilih investasi portfolio jangka pendek yang cepat menghasilkan. Bagi segmen ini, fitur deposito dengan bagi hasil bersaing dan benefit lain menjadi produk yang tepat untuk dikedepankan.

Keenam, climber, memiliki perilaku pekerja keras, ingin mencapai kebebasan finansial, pragmatis, namun memilih investasi yang terbatas. Climber adalah pekerja keras namun pragmatis, nilai perbankan syariah yang religius mungkin tidak tepat dikedepankan sebagai fitur unggulan bagi mereka. Keuntungan yang didapatlah yang menjadi daya tarik bagi mereka untuk memilih produk.

Ketujuh, follower memiliki perilaku ikut trend yang ada, eksis di komunitas masing-masing, dan pola manajemen aset yang terbatas pada tabungan atau reksadana. Perbankan syariah dapat mengedepankan fitur community banking atau trend komunitas, membuat produk agar dapat menjadi trending topic di masyarakat, sehingga cocok dengan perilaku mereka.

Kedelapan, flow-er berprilaku konservatif dan cenderung keras dalam beragama, namun memiliki pola investasi terbatas seperti tabungan dan emas. Segmen flow-er dapat di dekati dengan menampilkan fitur produk yang aman, baik aman secara resiko, maupun aman secara agama.

Berdasarkan jumlah dari kelompok tersebut, maka dapat disegmentasikan potensi kelas menengah sebagai berikut: Kelompok pertama adalah kelompok dengan share yang besar, climber $26,8 \%$, performer $15,6 \%$, flow-er 7,8 \% dan follower 6,25\%, yang menandakan bahwa kelompok terbesar dari kelas menengah Indonesia masih memiliki daya beli yang tidak terlalu tinggi. Mereka biasanya berada pada early phase yang berpendapatan 2-4 juta rupiah per bulan. Kelas ini kelihatan kurang potensial, namun karena jumlah yang banyak, segmen ini tidak bisa diabaikan. Melihat dari karakter dan perilaku lain selain daya beli, misalnya, perilaku dalam pola manajemen aset, kesemua segmen kelas low middle class ini punya potensi untuk berinvestasi dalam tabungan, emas, atau portfolio investasi sederhana lainnya.

Kelas yang kedua adalah kelompok dengan share yang lebih kecil, antara lain aspirator (23,98 \%), expert (4,9\%), trend setter (2,55\%), dan settler (11,91 $\%)$. Kelas ini merupakan kelas menengah yang sudah mapan, dengan sumber daya yang lebih baik. Bagi Industri perbankan, kelas ini malah menjadi kelas yang memiliki tantangan yang lebih besar. Pola manajemen aset kelas ini sudah lebih kompleks dan beragam. Mereka sudah berinvestasi pada portfolio yang lebih terdiversifikasi seperti reksadana, unit link, saham, dan surat berharga, surat utang negara, obligasi, ataupun pola investasi terbatas, seperti properti. 


\section{Potensi Perbankan Syariah di Pasar Kelas Menengah}

Kelas menengah merupakan pasar yang sangat baik untuk industri perbankan. Hal ini karena pasar kelas menengah sebagaimana telah diterangkan di atas, memiliki karekteristik berinvestasi dalam pelbagai macam cara. Pada kelas menengah yang paling besar, seperti segmen menengah-bawah (climber dan follower), karakteristik investasi yang mereka pilih adalah tabungan, dan deposito. Karakteristik ini tentu menjadi peluang untuk industri perbankan dalam hal menghimpun dana dari pihak ketiga. Lebih riil, dapat dilihat dari data mengenai kepemilikan produk keuangan. Alokasi pengeluaran per bulan untuk investasi yang paling tinggi adalah tabungan sebesar 14,1\%, investasi lain (5.3\%), dan asuransi $6.5 \%{ }^{16}$. Data lain yang menarik dan dapat dianalisis adalah estimasi uang beredar pada kalangan kelas menengah di Indonesia. Sebagai contoh, berdasarkan data, uang yang beredar di kelas menengah diestimasikan sebesar 129.6 trilyun ${ }^{17}$, maka akan kita dapati potensi tabungan yang dapat diraih untuk industri perbankan terutama dana pihak ketiga sebesar Rp 18 trilyun. Jumlah yang sangat besar yang tentu saja sangat menarik untuk diperebutkan oleh industri perbankan, termasuk bank syariah.

\section{Strategi Perbankan Syariah}

Melihat peluang yang sedemikian besar tersebut, maka ada beberapa strategi yang dapat ditempuh oleh perbankan syariah agar dapat bersaing dan berkompetisi dengan perbankan konvensional dalam menggarap kelas menengah. Salah satu yang menghubungkan kelas menengah Indonesia adalah mereka sangat familiar dengan pelbagai macam teknologi komunikasi, internet, dan media sosial. ${ }^{18}$

Indikator tersebut menguatkan asumsi bahwa kelas menengah Indonesia adalah orang-orang yang berpendidikan dan terbuka dengan informasi, yang

\footnotetext{
${ }^{16}$ Diolah dari data SUSENAS 2012 BPS dan hasil survai kelas menengah majalah SWA dan Inventure.

${ }^{17}$ Diolah dari data SUSENAS 2012 BPS dan hasil survai kelas menengah majalah SWA dan Inventure.

${ }^{18}$ Berdasarkan data dari Asosiasi Penyelenggara Jasa Internet Indonesia, Pengguna Internet pada tahun 2012 sudah mencapai 63 juta orang atau 24,23\% dari penduduk Indonesia, dari jumlah tersebut, sebanyak 53,5\% orang yang sudah bekerja. Lihat, www.antaraNews.com. Hasil survai lain yang fokus pada pemakaian internet kelas menengah menunjukkan bahwa pengguna internet di Indonesia 63 Juta, dari Survai 2012 MarkPlus Insight Netizen ini terkuak angka terbaru pengguna internet Indonesia saat ini yang berjumlah 61 juta orang, atau meningkat 6 juta dari tahun sebelumnya yang ada pada angka 55 juta. Pengguna internet Indonesia didominasi oleh kalangan middle-class, tercermin dari mayoritas pengguna internet Indonesia memiliki kendaraan: $88.6 \%$ memiliki motor, 17.4\% memiliki mobil, dan 16.8\% memiliki keduanya. Sumber: http://the-marketeers.com.
} 
berarti konsumen kelas menengah Indonesia adalah orang yang memiliki pengetahuan tentang produk yang baik. Keterbukaan akses terhadap internet dan media komunikasi lainnya juga menyebabkan asymmetric information pada kelas menengah menjadi berkurang, karena informasi bukan hanya didominasi oleh produk dan produsen saja, namun juga bisa berasal dari experience konsumen. Karakteristik ini kemudian berimbas pada pola konsumsi kelas menengah yang kerap mencoba hal yang baru dari info yang baru, atau berusaha mencari sebanyak mungkin tentang produk yang akan dipakainya.

Melihat fakta pemakaian internet di atas juga dapat berarti bahwa pelaku perbankan syariah, mulai aware untuk membangun komunikasi aktif dengan konsumernya melalui media alternatif tersebut. Media konvensional memang tidak bisa ditinggalkan, namun media baru, seperti internet, harus menjadi perhatian, mengingat dari tahun ke tahun, porsi penggunaan media internet semakin meningkat, dan sifat dari media internet yang lebih detil dari personal, bersifat timbal balik, yang justru disukai oleh kelas menengah yang bersifat kritis.

Sampai saat ini, harus diakui bahwa, perbankan syariah masih tertinggal dalam menggarap media internet sebagai ajang untuk mengomunikasikan produk-produknya ataupun meningkatkan pelayanan nasabah melaui media ini. ${ }^{19}$ Media internet yang digarap bukanlah terbatas pada aplikasi e-banking saja, namun lebih jauh lagi bagaimana memanfaatkan media internet sebagai media promosi yang dapat masuk bahkan pada jejaring sosial. Pemanfaatan media sosial dengan penggarapan website yang baik dapat mencakup enam hal, yaitu: content, konteks, customization, connection, community, dan commerze. Konten adalah keragaman isi dari website yang ditampilkan oleh bank syariah, termasuk update yang selalu dilakukan agar isi dari website tersebut tidak membosankan. Contex adalah bagaimana website dibuat menarik untuk dilihat. Customization adalah kemampuan untuk menjalankan menu yang personal dalam website tersebut. Connection adalah kemudahan dalam mengakses menu yang lain yang terdapat dalam website tersebut. Community adalah bagaimana situs tersebut mengembangkan komunitas di antara para anggotanya agar terus meningkat. Commerze adalah kemampuan situs tersebut dalam melakukan hal yang berhubungan dengan transaksi pelanggan ${ }^{20}$.

\footnotetext{
${ }^{19}$ berdasarkan pengunjung atau banyaknya diakses, maka peringkat pertama dari perbankan di Indonesia adalah: klikbca, kedua bankmandiri, ketiga BRI. Lihat, www.alexa.com.

${ }^{20}$ Lebih jelas bagaimana menilai ketertarikan pengunjung dalam mengunjungi sebuah website, baca dalam survai Majalah Marketing tentang promosi terbaik media digital pada Methodology the Best Digital \& Website, Majalah Marketing 10/XI/Oktober 2011, h. 42.
} 
Ada beberapa strategi umum yang dapat dipakai oleh perbankan syariah dalam menggarap pelbagai macam segmen. Pertama, membidik pasar yang sesuai dengan karakter segmen yang dituju. Perbankan syariah perlu menetapkan bahwa ada pelbagai macam segmen yang dapat digarap, untuk kemudian memperlakukan pelbagai macam segmen dengan cara yang berbeda atau fokus menggarap satu segmen tertentu yang paling potensial jika sumber daya terbatas. Perbankan syariah dapat memilih untuk menggarap segmen berdasarkan strategi segmentasi tunggal atau strategi multi segmental. Strategi multisegmental, jika perbankan syariah memiliki sumber daya yang kuat dan berlimpah, sedangkan untuk perbankan syariah yang memiliki sumber daya terbatas, dapat memilih segmentasi tunggal ${ }^{21}$. Sebagai contoh, ketika perbankan syariah menentukan terget pasar adalah segmen aspirator, maka strategi yang dilakukan disesuaikan dengan karakter dan perilaku segmen aspirator. Salah satu karakter aspirator adalah investasi jangka panjang, dalam manajemen aset, namum memiliki karakteristik dengan cita-cita berbagi pada sesama, maka diciptakanlah produk investasi yang mengakomodasi karakter tersebut. Misalnya produk perbankan yang ramah, dengan cara mem-bundle produk perbankan berdurasi panjang, seperti deposito satu tahun dengan filantropi, karena karakter aspirator adalah kecenderungan berjiwa sosial yang tinggi.

Kedua, melakukan inovasi yang berkelanjutan, karena kelas menengah adalah segmen yang kritis dan terbuka dengan pelbagai informasi yang saat ini sifatnya sudah dua arah. Informasi dua arah ini menyebabkan perusahaan dituntut untuk selalu mengakomodasi aspirasi dari konsumen terhadap produk tersebut. Salah satu cara yang dapat dilakukan adalah meminimalisasi komplen pelayanan dari nasabah bank syariah. Nasabah perbankan biasanya sangat peka dengan pelayanan, apalagi kelas menengah ke atas pada segmen midlle class upper. Produk yang tepat sebagai contoh, adalah tabungan premium atau preferent di mana nasabah mendapatkan pelayanan yang lebih personal.

Ketiga, menciptakan produk yang berkualitas. Salah satu karakteristik dari kelas menengah adalah perhatian terhadap produk yang lebih baik, dan peduli

\footnotetext{
${ }^{21}$ Segmentasi tunggal adalah sebuah strategi yang mensegmentasikan pasar ke dalam pelbagai macam segmen namun fokus pada satu segmen yang paling potensial dan paling berpeluang untuk dapat bersaing. Strtaegi segmen tunggal biasa dipakai oleh perusahaan yang emiliki sumber daya yang terbatas, atau tidak ingin berhadapan langsung dengan market leader. Strategi mukltisegmental adalah stratagi bermain pada semua segmen dan mengembangkan strategi yang unik pada masing segmen, Multisegmental biasanya dilakukan oleh perusahan dengan sumber daya yang cukup. Lebih jelasnya, lihat, Longenecker, Moore, Petty, Kewirausaahaan, Manajemen Usaha Kecil, terjemahan dari Small Bussines Management, (Jakarta: Salemba Empat, 2001), h. 130-131.
} 
dengan kualitas. Masuk pada pasar kelas menengah adalah kesiapan untuk menghasilkan produk yang berkualitas dan memiliki nilai lebih.

Keempat, memberikan akses yang luas kepada produk, baik dari segi distribusi maupun dari segi informasi. Kelas menengah Indonesia adalah orang yang memiliki mobilitas dan kesibukan yang cukup tinggi, sehingga akses yang mudah untuk mendapatkan produk atau informasi dapat berpengaruh signifikan terhadap produk. Produk perbankan syariah, misalnya, meningkatkan pelayanan kemudahan dalam pelbagai transaksi.

\section{Penutup}

Kelas menengah yang terus berkembang dan berpotensi sangat besar di indonesia adalah sebuah peluang bagi perbankan syariah untuk berkompetisi dan turut memperbutkan pasar gemuk tersebut. Pelbagai macam karakteristik dari kelas menengah adalah suatu masukan yang berharga sebagai bahan dasar melakukan segmentasi pasar yang tepat, targeting yang tepat, dan merumuskan strategi yang tepat dalam rangka menciptakan produk yang bisa diterima oleh pasa kelas menengah. []

\section{Pustaka Acuan}

\section{Buku dan Jurnal:}

Asian Development Bank, Key Indicator For Asia and Pasific 2010, SPECIAL CHAPTER The Rise of Asia's Middle Class, 41 ${ }^{\text {st }}$ Edition, August 2010

Banerjee, Abhijit, Esther Duflo, What is Middle Class about the Middle Classes around the World? Journal of Economic Perspectives , 22(2): 3-28 2008.

Kotler, Phillips, Marketing Management, Millenium Edition, New Jersey: Prentice Hall, 2000.

Longenecker, Justin, Carlos W Moore, Petty, William Petty, Kewirausaahaan ,

Manajemen Usaha Kecil, terj. Small Bussines Management, Jakarta: Salemba Empat, 2001.

Moore and Pareek, Marketing the Basics, New York: Routledge, 2006.

Mussry, dkk, The Next Marketing Strategy, That's Work, Jakarta: Gramedia, 2007. Majalah Marketing 10/XI/Oktober 2011

\section{Website dan Sumber Lainnya:}

SWA 02/XXII/23 Januari-6 Februari 2013

www.bps.go.id www.data.worldbank.org/country/id\#cp_wdi www.antaranews.com 
www.the-marketeers.com.

www.alexa.com. 